\title{
The Ottoman Sultan and his Non-Muslim Subjects in the Eyalet of Rumeli: Four Firmans Granting Privileges
}

\author{
Evi Psarrou, MA, Ph.D. \\ Ministry of Education- Greece \\ DOI: 10.29322/IJSRP.11.12.2021.p12053 \\ http://dx.doi.org/10.29322/IJSRP.11.12.2021.p12053
}

\begin{abstract}
The aim of this paper is to reveal the relations between the Ottoman Sultan and his non-Muslim subjects during the $18^{\text {th }}$ century in the Eyalet of Rumeli. In this context the paper reveals the difficulties the non-Muslim inhabitants faced in their every-day life, their relations with the local Ottoman authorities, their petitions and the latter's response to their grievances and requests, as well as the kind of concessions and importance of privileges granted to the inhabitants by the Sultan. Furthermore the paper reveals the Sultan's attitude and "duties" towards his subjects, his relations with his subordinate officers and the measures of governing the Empire. This study is also important because all the aforementioned information derive through the analysis of four original Ottoman firmans translated into the Greek language and published in "Historical Archives of Macedonia" serving as stimulus to further research on the issue. In fact the documents reflect the Sultan's rule over his non-Muslim subjects and their reciprocal relation in benefit of both sides.
\end{abstract}

Key terms: Granted privileges, Greek Ottoman subjects, Ottoman firmans, Ottoman Empire, Sancak of Selanik (Thessalonica), Ottoman Sultan.

\section{INTRODUCTION}

The practice of tolerance played a key role in shaping the relations of the Ottomans and their subjects during the Ottoman era, because it contributed to the maintenance of diversity among the inhabitants of the Empire, as well as the endurance of order in the Empire and the subjects' loyalty towards the Sultan. On the other hand the Sultan's tolerance towards his non-Muslim subjects applied on the condition that the latter accepted the superiority of power and religion of the Ottoman sovereign. In this content, the Sultan's tolerance and benevolence towards certain inhabitants are demonstrated through the analysis of four firmans granted to inhabitants of certain kazas that belonged to the Sancak of Salonica (Selanik, Thessaloniki). The Sancak of Salonica belonged to the Eyalet of Rumeli almost from the end of $14^{\text {th }}$ century up to 1826, whilst that year a new Eyalet was formed, the well-known Salonica (Selanik) Eyalet. In 1867 the Salonica Eyalet was transformed into the Salonica Vilayet in 1867.

\section{PRIVILEGES AS REGULATORY FACTOR IN THE RELATIONS OF THE EMPIRE AND ITS SUBJECTS}

A significant factor influencing the form of communities was certain "privileges" granted to them by the Sultans. An aspect of the Sultan's tolerance is demonstrated by written concessions, namely "privileges" in relation to political, economic and religious issues which created better circumstances for the inhabitants of those communities in which they were able to organise more efficiently both their lives and their enterprises. The privileges had a positive effect not only on the subjects of the Sultans, but on the Empire itself, as these concessions also contributed to the smooth running of Ottoman society. Besides, as one of the main aims of the Empire had been the conquest and, thereafter, the maintenance of the conquered lands, the grant of privileges mollified and placated the populations, which contributed to the success of the Empire.

Nevertheless, the greatest benefit for the subjects was that "the institution of privileges" gave them the opportunity to protect their rights and limit possible malpractices of the Ottoman local officers at the expense of the population. This can be explained by the fact that in the text of privileges ( $\pi \rho о$ онлакоi орлбноi) there was usually a strict record of the obligations, responsibilities and rights of the communities ${ }^{1}$. The authority of the Ottoman officials was restricted because of these privileges; and in the event they attempted to undermine or overrule the concessions, the community had the right to appeal directly to the High Porte, denouncing any infringements to the government and requesting the maintenance of its vested rights.

\footnotetext{
${ }^{1}$ On the institution of Greek Orthodox communities see: Psarrou, E. L., Ottoman rule in the Aegean. Chios during the 19thcentury, Centre -Periphery Relations, Athens: Papazissis Publishers, 2020, chapter 1, "The Communal institution during Ottoman period", pp. 27-40, where there is also extensive bibliography on the issue. 
It thus appears that a fairly close relationship was ensured between the central authority and these communities and furthermore, the privileges provided the latter with certain political autonomy, cultural and social independence, and secured a better financial development. $^{2}$

\section{GRANTING PRIVILEGES: THE FOUR FIRMANS}

\section{Document no 14 (firman): "Regarding the blackmails against the Christians of Kassandra" 3}

According to the document, the inhabitants of Kassandra addressed a petition to the Sultan ${ }^{4}$, explaining that the timariot (or timar holder,

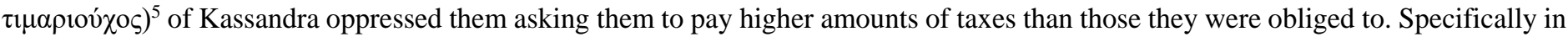
their petition they mentioned that the timariot received a greater amount of taxes than the prefixed amount which had been earlier determined in a previous firman. This fixed amount was also noted in a tax registry and was allocated to the inhabitants of the area in accordance to their financial situation. Nevertheless the timar-holder collected the fixed amount of taxes and on top of that he also collected an amount for his personal benefit. In addition, he bought the peasants' cereals, silk and wheat at a very low price, and -as it is mentioned in the document- "he (the timar-holder) acted unjustly towards them and he oppressed them".

The people of Kassandra asked for an official representative of the Sultan to be appointed by the Ottoman Government in order to investigate the issue and restore the law. Following the investigation, in case the sultan's envoy ascertained that the peasants' complaints were true and valid, the Sultan would then issue a decree ordering the abusively collected money to be returned to the peasants. The Sultan eventually sent a representative and asked the $k a d i^{6}$ to summon the adversaries before him and settle the matter at hand. The Sultan asked the kadi to issue a document ordering the return of the inhabitant's money In case they were right. Furthermore, he asked the kadi to prevent in the future such injustices against the inhabitants and not allow anyone to act contrary to his orders and violate his wishes.

The document is written in Constantinople (Istanbul) and dated 2 February 1696.

\section{Document no 22 (firman), "Regarding the cessation of oppression against the inhabitants of Visoka" 7}

The inhabitants of the village $(k a z a)^{8}$ of Vissoka and the inhabitants of the villages around the hass ${ }^{9}$ of the kaza of Visoka ${ }^{10}$ dispatched a report to the High Porte explaining that they had payed off their fixed amount of taxes for that year. However, although the imperial hass were free of any other obligations and no one could trouble them, high ranking Ottoman officers oppressed them demanding to pay additional heavy taxes without the Sultan's ${ }^{11}$ consent.

In addition, according to the inhabitants' petition, some people who claimed to be envoys of the pasha or the mutesselim ${ }^{12}$, put pressure on them trying to extort money gifts and food. Following these annoying events, the inhabitants dispatched the petition to the Sultan pleading him to halt the "suffering" and injustices against them, as well as to dismiss all those officials who oppressed them. Next the Sultan ordered the kadi to take an interest himself on the events and ensure that order and justice would be restored. Furthermore the Sultan asked the kadi to be vigilant and not to allow anyone to bother the inhabitants of Visoka and furthermore to strictly prevent those who would attempt to oppress the inhabitants and cause them any kind of distraught.

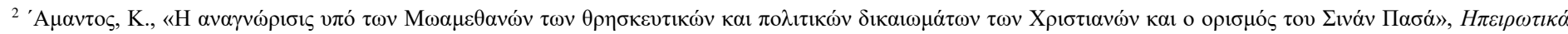

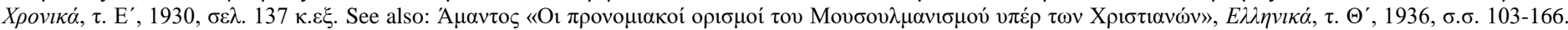

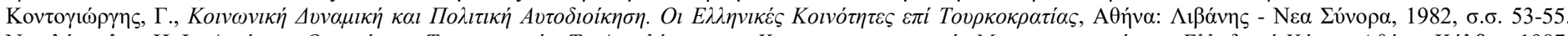

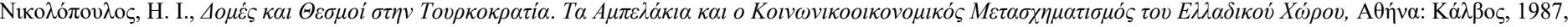
б.б. 44-46.

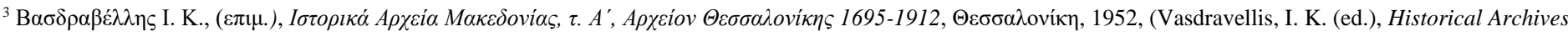

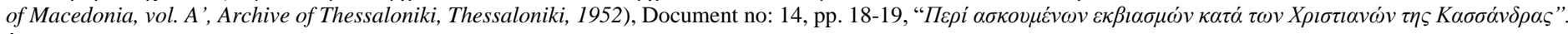

${ }^{4}$ The name of the Sultan is not mentioned in the firman. Nevertheless, the document refers to Sultan Mustafa II (reign: 1695-1703).

${ }^{5}$ The timar was a piece of land granted by the Ottoman Sultans between $14^{\text {th }}-16^{\text {th }}$ centuries with a tax revenue annual value of less than 20,000 piastres $(\underline{a k c ̧ e s})$. A timariot or timar-holder had the authorization to have control over arable lands or lands possessed by peasants within the timar territory. The ownership of the land belonged to the Empire. The timariot had the right to manage the peasantry and collect part of the fixed amount of the tax revenues of these lands in return for his military service to the Empire.

${ }^{6}$ Kadi: a judge of the Ottoman court of justice who was learned in Islamic law.

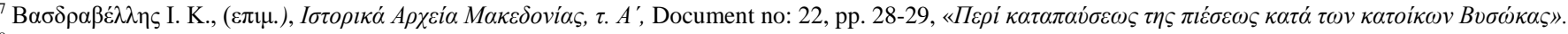

${ }^{8}$ An Ottoman administrative division/district subject to the legal and administrative jurisdiction of a kadi up to the Tanzimat Reform when the administrative duties of the kadi were transferred to a kaymakam namely a governor.

${ }^{9}$ Hass: in the Ottoman administrative- military classification of land, a hass was an estate with revenue. The revenues were allocated to the Sultan or other high ranking Ottoman officers.

${ }^{10}$ Visoka: Today's "Ossa”, a village of the Municipality of Lagkadas. The village's older name Visoka derives from a Slavic word.

${ }^{11}$ The name of the Sultan is not mentioned in the firman. The document again refers to Sultan Mustafa II (reign: 1695-1703).

${ }^{12}$ Mutesselim: an administrative officer, lieutenant- governor of an administrative district, responsible for collecting the taxes and control the population. Before the Tanzimat Reform the mutesselim could also be the tax-farmer of that specific district.

This publication is licensed under Creative Commons Attribution CC BY.

http://dx.doi.org/10.29322/IJSRP.11.12.2021.p12053

WWW.ijsrp.org
} 
The sultan in the same firman emphasized that all villages which were imperial hass were free from any financial burden, provided that the peasants paid their fixed taxes. Concluding the firman, he asked the kadi to reveal to him the persons who caused distressed to the inhabitants acting at their own will ignoring the Sultan's orders.

The document is written in Andrianoupolis (Edirne) and dated 15 April 1697.

\section{Document no 48 (firman): "Regarding the prohibition of oppression against the reaya"13.}

This document is a firman which the Sultan ${ }^{14}$ addressed to the commander of the forte guard of Thessaloniki, the kadi of Thessaloniki, the kadi of Veria as well as a certain Hatzi Ahmet who was appointed by the Sultan to collect the tax of the "infidels" (of the nonMuslim subjects of the Sultan, also called zimmi/dhimmi) and the Jews. The Sultan stated that he became aware of an information about the "raw greed of the tax collectors regarding the poll tax (cizye)". Specifically, the tax collectors did not allocate the tax documents (in the Greek text $\left.\delta \varepsilon \lambda \tau_{i} \alpha\right)$ to the Greeks, Jews and Armenians who lived in the sancak (larger administrative district) of Thessaloniki. According to these documents the Sultans' subjects of the sancak were liable to pay poll tax of a certain amount. The Sultan clarified that in these tax documents the names and details of the subjects who were accountable to the poll tax were carefully noted down, as well as the specific amount owed to the Ottoman Treasury by each one of them. Nevertheless, as the Sultan was informed, the tax documents which the tax collectors gave to the reayas ${ }^{15}$ included higher amount of taxes than they actually owed. In addition, all the tax documents that were not allocated to reayas, were handed over by force to the "infidels" living in the villages (kazas) of the sancak of Thessaloniki. The latter could not afford to pay the taxes demanded by the tax collectors and fled to other villages (kazas) away from the sancak. For these reasons the sultan gave the following order to his officials: "you must henceforth ensure that the reayas would live in peace and quiet". In this firman the Sultan went one step further and clearly stated that the tax collectors who did not comply with his orders and continued to violate the terms of the berats ${ }^{16}$ held by certain inhabitants, would be beheaded. He also asked his officers to ensure that the reayas who had fled to neighbouring kazas would return to their homes.

Trying to persuade them to return back to their homes, the Sultan ordered his subordinates to withdraw and take back only for that year 500 tax documents. Following, certain Greeks, Armenians and Jews of the sancak of Thessaloniki would be liable for paying off these taxes. Next the Sultan instructed his subordinates to hand the tax documents over to the inhabitants of the kaza of Veroia whose according to the Sultan's writings- financial situation was far better than the sancak of Thessaloniki's inhabitants.

He asked the tax documents to be handed over to the "infidels" (meaning the Christians) and the Jews of the kaza of Veroia. He also emphasised that their names would be written on the documents. He did not fail to mention once again that if anyone involved in the poll tax issue acted contrary to his will and the content of the berats causing upset to the Empire, turmoil to his subjects and financial loss to the Imperial Treasury, would be beheaded. Alike, if anyone tried to protect the reayas of the kaza of Veroia not allocating to them the taxes due or even if anyone accountable in paying the aforementioned taxes secretly disappeared renouncing his obligation to the state, then the Ottoman officials were bound to record all the disobedient reayas, dispatch the list with their names to the High Porte and ultimately behead all of them "because the public sector has suffered a significant financial loss and we must exemplary deal with this matter", as the Sultan himself underlined in the firman.

Next the sultan emphasized once more that the taxpayers must assume their responsibilities to the state. The Sultan resuming his orders insisted that the tax documents should be allocated according to the inhabitants' financial situation and therefore their tax capacity. The Sultan also repeated that those who hid refusing to pay their share would be strictly punished. Then these reayas, having paid their taxes to the Ottoman Treasury, would always have to bring with them the tax documents proving that they had fulfilled their obligations. On the contrary, if they had not had the documents with them, according to the Sultan's orders, they would be immediately arrested. Finally the Sultan once again asked from the tax collector to put his greatest effort in collecting the taxes for the benefit of the Empire, to protect the reayas from any injustices at their expense and "above all to not deviate from the law". Lastly he expressed the wish all his servants to act in accordance with his decree.

The firman was written in Constantinople (Istanbul) on 20 November 1705.

\section{Document no 75 (firman): " Regarding the prohibition of oppressive measures against Chalkidiki"17}

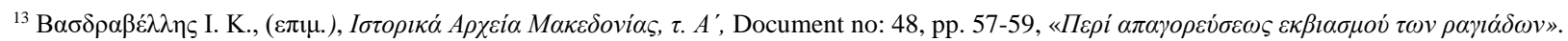

${ }^{14}$ The document refers to Sultan II (reign: 1703-1730).

${ }^{15}$ Reaya: a member of the tax-paying lower class of Ottoman society (literally flock), including Christians, Muslims and Jews who were taxed. However the term eventually referred only to non-Muslim Subjects.

${ }^{16}$ Berat: A concession document of a privilege or right. A non-Muslim bearer of a berat document usually enjoyed various tax exemptions.

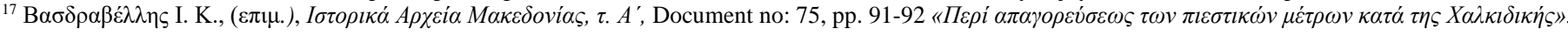
This publication is licensed under Creative Commons Attribution CC BY.

http://dx.doi.org/10.29322/IJSRP.11.12.2021.p12053

WWW.ijsrp.org
} 
The Sultan addressed this firman to the kadi of Thessaloniki in relation to the region of Kassandra, which was a vakif (or vakf) ${ }^{18}$ under the immediate direction and supervision of the chief eunuch (" $\alpha \rho \chi 1 \varepsilon v v o v$ $\chi \circ \varsigma^{\prime}$ in the Greek text) ${ }^{19}$ of the Sultan's ${ }^{20}$ palaces. The vakif of Kassandra could be rented to anyone who wished to lease it, according to the terms of the vakifs. The income and profits of the vakif of Kassandra were spent for the gifts of the poor living in the holy cities of Mecca and Medina, as well as the salary of the Imperial entourage, whilst the excess of the income covered the expenses of the vakif itself, and sometimes were spend for provisions given to the deprived people of the area.

However, the Sultan stated that the valis (vali: administrative title- governor) ${ }^{21}$ of the district on their tour round the vakif asked from the reayas to cover their journey's expenses. Not only these officers, but even the kadi and his representative in the Peninsula (namely Chalkidiki) also charged the reayas of Kassandra with the expenses of their stay in the vakif, receiving also certain amounts of money on their demand. Furthermore the reayas were asked to bear the costs for the maintenance of the menzils ${ }^{22}$. All these, the sultan noted, caused great anxiety to his subjects because the incident "was a blatant injustice against them".

Because of this oppressive situation the vakf's reayas scattered in the surrounding areas, the vakif's tenant annulled the leasing agreement and no one else was willing to rent the area, thus causing great upheaval in the hitherto well-functioning of the vakif. The Sultan then emphasized that according to the land registry kept in the Palace the reayas who lived within Kassandra's grazing land and in the nearby

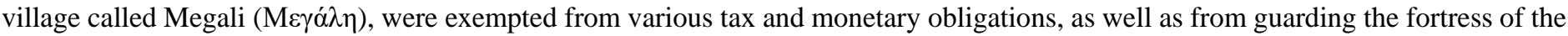
area, paying for barley, transferring timber and being house servants. They were generally exempt from the taxation.

Furthermore the document mentions that the Sultan in consultation with his archdefterdar ${ }^{23}$ would issue a firman confirming once again that the residents of the vakif of Kassandras would be free from any financial obligation as well as any contribution for the operation of the post offices, thus aiming at relieving the "poor reayas" from their burdens, restoring their peaceful lives, not reducing the financial resources of the vakif and consequently the imperial entourage's financial compensation.

The Sultan also underlined that the mutasarrif $s^{24}$ and the kadis of the sancak of Thessaloniki should neither have in the future any financial claims and demands nor should persecute the poor reayas of Kassandra. He also added that in case somebody had abusively extorted money from them, there should be a refund for them at the expenses of the kadi's Law Court. Finally the Sultan repeated that he was interesting in his subjects' welfare and none had the right to cause them turmoil.

The document was written in Constantinople (Istanbul) on 15 May 1709.

\section{THE SULTANS' RELATIONS WITH HIS SUBJECTS}

However it should be noted that the Sultan's attitude towards his subjects could be explained within the context of the Empire's organization and consolidation of power. Specifically the Sultan should be perceived as a protector and not as a tyrant. He was the one who safeguarded his suffering flock

According to the subjects' perception the Sultan should be a strong an effective leader capable of offering security and peace. Furthermore it was his obligation to offer them his protection in the event of injustice against them by the ottoman officers. On several occasions the latter violated their duty resulting at the oppression of the non-Muslim subjects. It was then that the Sultan ought to act in favour of his subjects and safeguard their rights. In this context special care had to be taken for taxation as it was not uncommon for the Ottoman officials to extort from the non-Muslim subjects illegally money and several gifts. The Sultan once again ought to bring back to order his officers and restore justice to the benefit of his subject. Thus the Sultan's attitude towards his subjects secured their trust in him and created a bond of loyalty between them. Besides, their loyalty was a necessary condition for the Sultan himself in order to secure allegiance and efficiently govern his vast multicultural Empire. On the other hand since the Sultan demonstrated a caring and

\footnotetext{
${ }^{18}$ Psarrou, E. L., Ottoman rule in the Aegean, pp. 266-268, p. 266, "The word vakif means a tribute or votive offering ( $\left.\alpha \varphi \iota^{\prime} \rho \omega \mu \alpha\right)$, namely an object or property offered to further a charitable or sacred cause. The original owner of the property or land, endowed it in support of pious foundations with the aim of fulfilling his religious desires. The act of endowing and simultaneously establishing somebody's property as a vakif for the public welfare, according to religious beliefs, pleased God and helped in the redemption of one's soul. The status of the vakif was irrevocable, which meant that their ownership was non-transferable".

${ }^{19}$ There were two eunuchs serving in the Sultan's Palace in Constantinople, the Kapi Agha who was in charge of the Palace by the late $16^{\text {th }}$ century until his post was taken over by the Kizlar Agha, namely the chief Black Eunuch who was the head of the eunuchs that guarded the Imperial Harem of the Sultan. It is not clear in the Greek text to whom the Sultan refers to.

20 The document refers to Sultan II (reign: 1703-1730).

${ }^{21}$ Vali: administrative title- governor of a district.

${ }^{22}$ Menzil: A system operated by cavalry "postmen" transmitting the orders of the Sultan to the provinces and returning information about what was happening there. They alternated in stations $(\mu \varepsilon v \zeta \hat{\zeta} \lambda-\chi \alpha v \varepsilon \delta \varepsilon \varepsilon \varsigma)$ and constituted a special battalion with special privileges and they also received a salary from the Treasury.

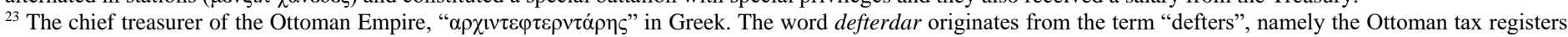
that the defterdars were in charge of.

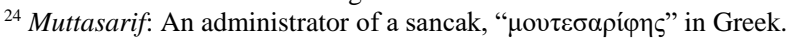

This publication is licensed under Creative Commons Attribution CC BY.

http://dx.doi.org/10.29322/IJSRP.11.12.2021.p12053

www.ijsrp.org 
ISSN 2250-3153

generous attitude, like a "father figure", their subjects ought to acknowledge his generosity and benevolence and in turn to reciprocate his graciousness. Therefore they had to be obedient and devoted to him, but above all they had to be consistent in paying their taxes. According to the above it becomes evident that there should be a commitment on both sides and furthermore there should be a high degree of mutuality and reciprocity in their relation for the benefit of both parties as already said.

\title{
V. CONCLUSION
}

Examining the documents, it becomes apparent that the Sultan's intentions and orders were explicit and unambiguous. Even more, he was absolute and stern with his subordinate Ottoman officials. He demanded his instructions to be followed to the letter and his desires to be fulfilled. In achieving his goal he even punished his own officials imposing the death penalty on them.

Apparently he cared about his subjects and tried to be fair towards them, provided that they were consistent in their obligations towards the Empire. He was attentive to their grievances and tried to ascertain possible injustices against them and eventually satisfy their requests and needs. Eventually the Sultan's subjects were benefited from special regulations on condition they unarguably accepted the inferior social and religious status of the Ottomans.

The Sultan granted to his subjects certain concessions issuing written orders that included "privileges". Thus he attained the profile of a just and merciful leader whilst respectively the bond between him and his "folk" strengthened. Summarising, the Sultan protected his suffering and poor subjects provided they paid their taxes, threatened and punished his officials in case they neglected his orders and consequently the devoted subjects praised their lord.

\section{REFERENCES}

[1] Abou-El-Haj, R.A., Formation of the Modern State: the Ottoman Empire $16^{\text {th }}$ to $19^{\text {th }}$ centuries, Albany: State University of New York Press, 1991.

[2] Braude, B., \& Lewis, B., (eds.), Christians and Jews in the Ottoman Empire: the functioning of a plural society, vol. 1, New York: Holmes \& Meier Publishers Inc., 1982.

[3] Dipratu, R., Regulating Non-Muslim Communities in the 17th Ottoman Empire. Catholics and Capitulations, Routledge, 2021.

[4] Faroqhi S (ed.), The Cambridge History of Turkey. v.3, The Later Ottoman Empire, 1603-1839, Cambridge: Cambridge University Press, 2006.

[5] Green, M., A shared world: Christians and Muslims in the early Modern Mediterranean, Princeton University Press, Princeton, 2000.

[6] Inalcik, H., "Centralization and Decentralization in Ottoman Administration" in Studies in eighteenth century Islamic History, T. Naff and R. Owen (eds.), pp. 27-52, Carbondale: Southern Illinois University Press, 1977.

[7] Inalcik, H., "The Ottoman Empire and its effects upon the reaya", The Ottoman Empire. Conquest, Organization and Economy, no XIII, London, 1978.

[8] Koliopoulos, I., \& Hassiotis, I., (eds.) Modern and Contemporary Macedonia, Thessaloniki: Paratiritis Publishing House, 1997.

[9] Özil, A., Orthodox Christians in the Late Ottoman Empire: A Study of Communal Relations in Anatolia. New York: Routledge, 2013.

[10] Pantazopoulos, N., "Community laws and customs of Western Macedonia under Ottoman rule", Balkan Studies, v. 2, no 3, 1961-1962, pp. 1-22.

[11] Quataert, D., The Ottoman Empire 1700-1922, $2^{\text {nd }}$ ed., Cambridge University Press, 2005

[12] Sugar, p., Southeastern Europe under Ottoman Rule, 1354-1804, (A History of East Central Europe), Vol. 5, University of Washington Press; Reprint edition (October $1,1983)$

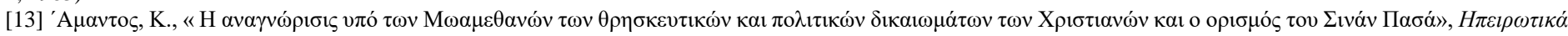

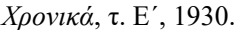

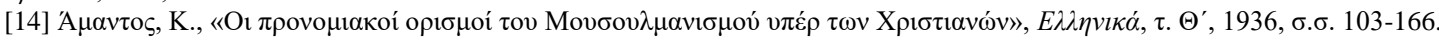

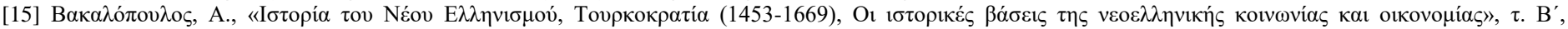

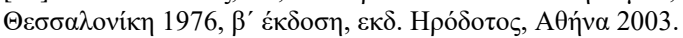

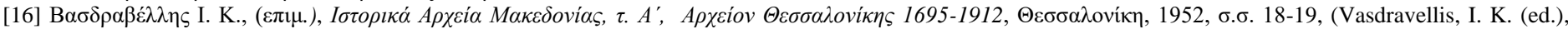
Historical Archives of Macedonia, vol. A', Archive of Thessaloniki, Thessaloniki, 1952).

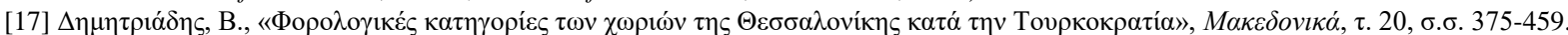

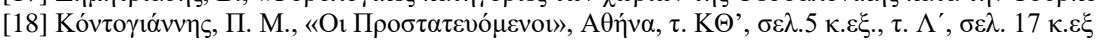

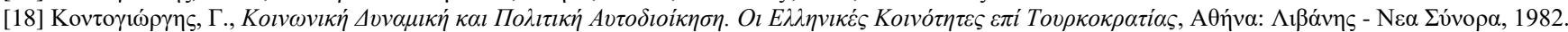

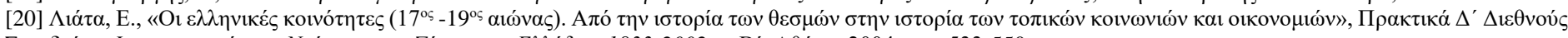

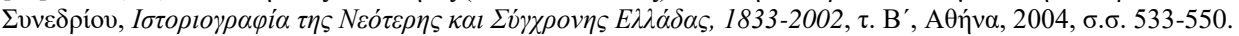

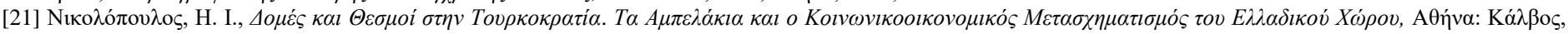
1987.

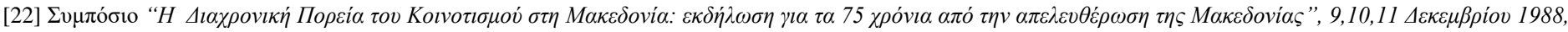

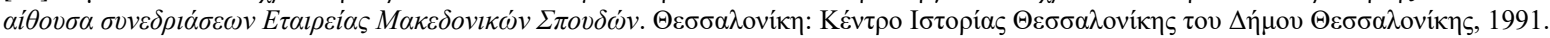

\author{
AUTHOR \\ Evi Psarrou \\ MA, University of Newcastle upon Tyne-UK \\ $\mathrm{PhD}$, University of Birmingham-UK \\ Ministry of Education - Greece \\ e-mail: evipsarou@gmail.com
}

Correspondence Author: Evi Psarrou

This publication is licensed under Creative Commons Attribution CC BY.

http://dx.doi.org/10.29322/IJSRP.11.12.2021.p12053

WwW.ijsrp.org 